LAWRENCE LIVERMORE N A TION AL LABORATORY

Preparing for Terrorist Attacks that Utlize Next Generation Pathogens

J. Patrick Fitch

January 14, 2005 
This document was prepared as an account of work sponsored by an agency of the United States Government. Neither the United States Government nor the University of California nor any of their employees, makes any warranty, express or implied, or assumes any legal liability or responsibility for the accuracy, completeness, or usefulness of any information, apparatus, product, or process disclosed, or represents that its use would not infringe privately owned rights. Reference herein to any specific commercial product, process, or service by trade name, trademark, manufacturer, or otherwise, does not necessarily constitute or imply its endorsement, recommendation, or favoring by the United States Government or the University of California. The views and opinions of authors expressed herein do not necessarily state or reflect those of the United States Government or the University of California, and shall not be used for advertising or product endorsement purposes.

This work was performed under the auspices of the U.S. Department of Energy by University of California, Lawrence Livermore National Laboratory under Contract W-7405-Eng-48. 


\section{Preparing for Terrorist Attacks that Use Next-Generation Pathogens}

Of all the challenges to homeland security, developing and implementing strategies for dealing with attacks that use "next-generation" pathogens, including novel or engineered agents, is one of the most important. During these attacks, it can be difficult to discriminate between a natural outbreak and an attack, to identify and characterize the causative agent, and to prioritize interventions. A consequence of not identifying and responding to an attack at an early stage is the increased spread of infection in the population and the associated increases in morbidity, mortality, and cost of quarantine. We examine three prior natural events that allow us to characterize the potential enormity of the impact of an attack that uses next generation pathogens, and to identify R\&D and policy objectives that would significantly reduce the likelihood of severe national scale consequences.

Several times in the past century, the world witnessed the emergence of previously unknown pathogens that caused or had the potential for causing widespread deaths. The 1918-19 "Spanish flu" pandemic alone caused as many American deaths as all the wars in this country's history. That pandemic, together with the 2002-03 severe acute respiratory syndrome (SARS) outbreak, and the 1976-77 "swine flu" mass vaccination program, can be used to illustrate the power of a next-generation bioagent, the importance of well-integrated response, and the policy decisions needed for mass intervention.

In the Spanish flu pandemic, initial cases of influenza appeared around September 8, 1918, in Camp Devens, Massachusetts. Within five weeks, the entire country was affected, and the death rate peaked at about 50 per thousand. The pandemic was unusual in both its death rate and the rate at which it spread. The reasons for the virulence and contagion of that strain are still not understood. This pandemic hit during World War I, when large numbers of people were living in very close proximity to one another, railroads provided the fastest means of public travel, and no effective treatment existed. The 1918 pandemic is estimated to have killed more than 670,000 Americans and over 48 million people worldwide. With a 1918 population of 103 million, the U.S. death toll was roughly 6.5 people per thousand. A similar death rate today would result in nearly 2 million deaths, eclipsing the potential of other attacks except for nuclear explosion.

The SARS outbreak also spread widely and rapidly, in large part due to global air travel. However, it received outstanding and unprecedented worldwide cooperation and thus provides a base timeline for a feasible response. It is now known that the initial cases of SARS occurred in Guangdong Province, South China, around November 16, 2002. About 90 days later, on February 14, 2003, the World Health Organization (WHO) Weekly Epidemiological Record (WER 7/2003) reported 305 cases and 5 deaths of atypical pneumonia. This WER report is the surveillance trigger that serves as "time zero" for the global SARS response. Thirty-eight days after the report, a new coronavirus was isolated from patients with SARS. Sixty-one days after time zero, this new virus was shown to be the causative agent of SARS. About 80 days after time zero, researchers were able to characterize the survival duration of the SARS virus in feces, urine, and on plastic surfaces as well as other information needed for managing quarantine strategies and health-care 
practices. Beyond quarantine, no specific mitigation or intervention options were available in the 80 days.

While the response to SARS is considered by many to be representative of today's best response capabilities, those timelines would not have been effective for dealing with the 191819 pandemic (Figure 1). It took 90 days for surveillance to trigger response and 80 days after surveillance to positively identify and begin characterization of the SARS virus. In half that time, the 1918 pandemic had swept the country and was already diminishing.

The quarantine strategies used to contain the SARS outbreak demonstrate the importance of dealing with an incident while it is still relatively localized. Such strategies are much more difficult, perhaps impossible, to implement once a disease has spread. Today, we must also consider the possibility of a

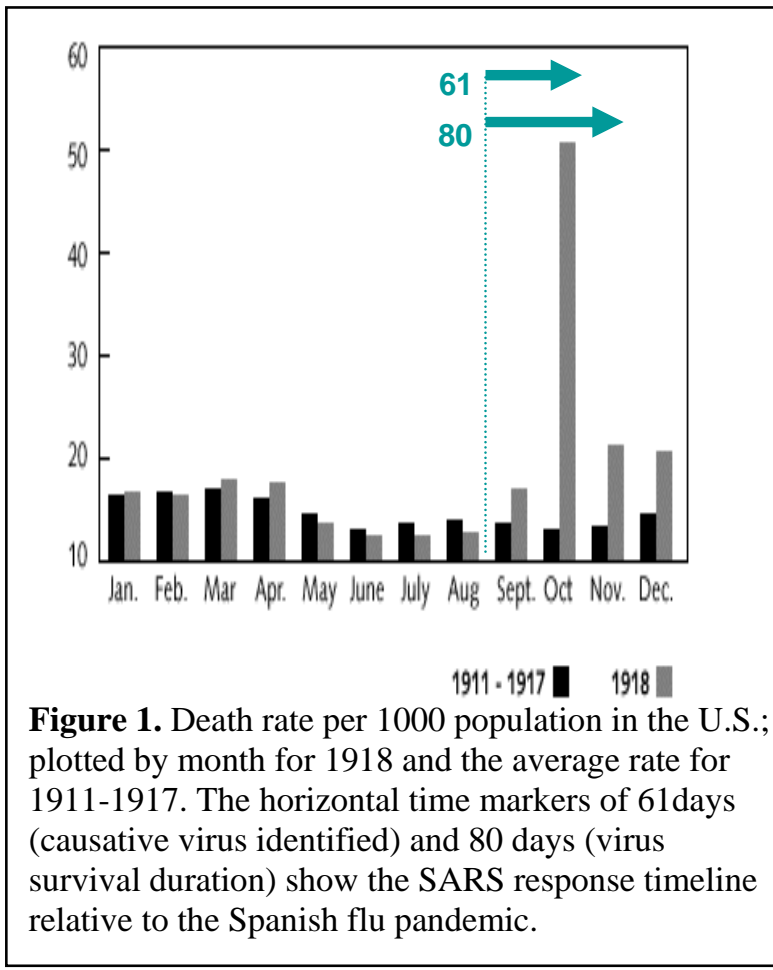
terrorist attack that could take place simultaneously at multiple places across the country or globe, using a pathogen whose virulence and contagion is equal to or greater that of the naturally occurring outbreaks, and for which no intervention is currently available.

An effective response to a terrorist attack using a pathogen similar in virulence and contagion to the 1918 flu will require surveillance and characterization many times more rapid than was accomplished for SARS. However, dramatic improvements in surveillance and characterization alone are not enough. A vaccine was produced in the swine flu program launched by the Federal government in March 1976. The start of inoculations, however, was delayed by liability and other issues until October 1, 1976-over 180 days after the program started. The 1976-77 swine flu program demonstrated that regulatory, legal, and policy delays can stymie a timely response even when vaccination and other interventions have been identified. In order to respond effectively to such an event, the U.S. must dramatically shorten the response times. This will require an unprecedented and integrated approach that addresses both scientific and policy issues.

We propose a strategy to meet the next-generation pathogen challenge. This architecture has four integrated components each with specific operational responsibilities: surveillance, pathogen characterization, identification and creation of mitigation options, and intervention. Assessment of natural outbreak timelines provides the response goals (Table 1).

- Surveillance provides recognition of an event as early as possible.

- Pathogen characterization quickly generates critical information about the bioagent, including isolation, identification, and in-depth analysis.

- Identification and creation of mitigation options must be done rapidly and include risks, cost-benefit analysis, and predicted effects. 
- Intervention executes the mitigation priorities including enhancing surveillance capabilities to assess effectiveness of the response.

Table 1. Bioterrorist event response goals (derived from the 1918 flu timeline) are compared with the SARS benchmark.

\begin{tabular}{|c|c|c|c|c|}
\hline & Surveillance & $\begin{array}{c}\text { Pathogen } \\
\text { Characterization }\end{array}$ & $\begin{array}{l}\text { Mitigation } \\
\text { Options }\end{array}$ & Intervention \\
\hline SARS & $\begin{array}{l}90 \text { Days } \\
\text { - Index case to } \\
\text { recognition } \\
\text { of outbreak }\end{array}$ & $\begin{array}{l}60 \text { Days } \\
\text { - Surveillance } \\
\text { detection to full } \\
\text { characterization } \\
\text { of pathogen }\end{array}$ & $\begin{array}{l}\text { Weeks to Months } \\
\text { - Pathogen } \\
\text { characterization } \\
\text { to identification } \\
\text { of mitigation } \\
\text { options }\end{array}$ & $\begin{array}{l}\text { Weeks to Months/Years } \\
\text { - Implementation of } \\
\text { selected response }\end{array}$ \\
\hline Goal & $\begin{array}{l}\text { Days to Week } \\
\text { - Detection of } \\
\text { novel and } \\
\text { genetically } \\
\text { modified } \\
\text { bioagents } \\
\text { - Human and } \\
\text { agricultural/v } \\
\text { eterinary } \\
\text { surveillance } \\
\text { - Multiplexed } \\
\text { tests for } \\
\text { health and } \\
\text { security }\end{array}$ & $\begin{array}{l}\text { Days } \\
\text { - Rapid biological, } \\
\text { chemical, } \\
\text { physical, and } \\
\text { functional } \\
\text { characterization } \\
\text { of pathogen } \\
\text { - Identification of } \\
\text { all microbes in a } \\
\text { sample } \\
\text { - Bedside/pen/ in- } \\
\text { the-field } \\
\text { diagnostics }\end{array}$ & $\begin{array}{l}\text { Days to Week } \\
\text { - Identification of } \\
\text { useful existing } \\
\text { mitigation } \\
\text { options } \\
\text { - Development of } \\
\text { alternative } \\
\text { mitigations } \\
\text { - Analysis of range } \\
\text { of interventions } \\
\text { (low to high } \\
\text { regret) }\end{array}$ & $\begin{array}{l}\text { Week } \\
\text { - Reduced timelines } \\
\text { using template } \\
\text { strategies for } \\
\text { response, } \\
\text { communication, } \\
\text { indemnification, } \\
\text { regulatory issues, etc. } \\
\text { - Rapid manufacturing, } \\
\text { distribution, and } \\
\text { administration of } \\
\text { interventions } \\
\text { - Monitoring of } \\
\text { intervention } \\
\text { effectiveness }\end{array}$ \\
\hline
\end{tabular}

These are unquestionably ambitious goals, but advances in many technological fields make major advances possible. For example, powerful sequencing techniques coupled with extensive bioinformatics libraries allow analyses of newly discovered pathogens in days rather than years. And while bioengineering might be a tool used by terrorists to create new pathogens, it can be harnessed to create new vaccines too. In order to accelerate the R\&D activities and maximize the likelihood of success, the U.S. needs an aggressive spiral development process that emphasizes significant near-term capability enhancements, translation through to field testing in dual-use applications, and a long-term goal of developing antidotes and protective interventions on the time scales required to counter terrorist events that use biological agents. Dual-use applications are particularly important, because they not only allow field evaluation of new technologies but also provide real-world data on such critical operational issues such as cost, training, and effectiveness. Near-term capability enhancements can and should be one of the hallmarks of this effort.

An aggressive program that builds on and goes beyond the BioShield legislation is required to develop appropriate policies that address critical issues in communications, regulatory 
approvals, and indemnification. In order to be effective during an attack, these policies will have to support rapid decision making across government as well as pre-arranged and dynamic interactions to the local level and with the private sector.

Given appropriate resources, several major milestones could be met early in the program. By the end of the first year, four major milestones could be met:

- Detection of antibiotic-resistant Bacillus anthracis in environmental samples could be piloted in a major metropolitan area and deployed in the DHS BioWatch system.

- Demonstration of enhanced surveillance for a wide range of pathogens is feasible using deeply multiplexed clinical diagnostics. This surveillance technique could be demonstrated in a variety of dual-use environments that have potential near-term benefit to the quality and cost of health care. One high-leverage demonstration that we have identified reduces the use of broad-spectrum antibiotics.

- An independent national study on scientific and policy issues could be conducted to provide an integrated assessment of opportunities and challenges.

- National architecture, gap analysis, and policy roadmap would be drafted.

By the end of the third year, the program would meet four additional major milestones:

- A national architecture for achieving rapid intervention would be documented.

- A scientific comparison of options for the rapid development of antidotes and protective interventions would be completed and peer-reviewed.

- A regional surveillance pilot program based on clinical diagnostics will demonstrate the ability to detect disease outbreaks in one week or less.

- A system for categorizing the microbial content of a sample will be demonstrated on "unknown death" and "unknown respiratory illness" archives. This will add to our understanding of pathogens in the community and will test our capabilities for rapidly identifying unknown pathogens.

By the end of the fifth year, a technology proof-of-principle for rapid intervention, an interagency rapid intervention plan, and translation of components of surveillance and characterization to operations will be completed. These ambitious goals require investments in all of the preceding years of the program and significant resources in the following years to go from proof-of-principle to demonstrated scaling, safety, and efficacy-an integration of science, industrial-scale processes, and policy.

In order to create options and decision processes for rapid intervention during a wide-scale bioterrorist attack or a 1918-scale pandemic, we must significantly shorten the response times for surveillance, pathogen characterization, mitigation option creation and evaluation, and intervention. In addressing this homeland security challenge, science and technology becomes an advantage when we are the most rapid adopters and integrators.

Contact fitch2@llnl.gov for more information. The author acknowledges many collaborators in homeland security, public health, and law enforcement in government, academia and industry. More detailed descriptions of the four components of the architecture are being developed collaboratively.

Work performed under the auspices of the U.S. Department of Energy by Lawrence Livermore National Laboratory under Contract W-7405-ENG-48. 